\title{
Analysis of the $\mathrm{CCK}_{\mathrm{B}}$ receptor antagonism of virginiamycin in guinea-pig ileum longitudinal myenteric plexus
}

\author{
${ }^{1}$ M. Corsi, G. Pojani, G. Dal Forno, C. Pietra, G. Gaviraghi \& D. Trist \\ Glaxo Research Laboratories, 37135 Verona, Italy
}

1 Virginiamycin, a macrolide reported to bind selectively to $\mathrm{CCK}_{\mathrm{B}} /$ gastrin receptors has been studied in a functional test, namely cholecystokinin-induced contraction of guinea-pig ileum myenteric plexus (LMMP).

2 Virginiamycin $(1-10 \mu \mathrm{M})$ antagonized the selective $\mathrm{CCK}_{\mathrm{B}}$ agonist cholecystokinin tetrapeptide $(\mathrm{CCK}-4)$. The antagonism appeared not to be competitive as the highest concentration $(10 \mu \mathrm{M})$ caused a reduction of its maximal effect. An apparent $\mathrm{pA}_{2}$ of $6.64 \pm 0.06$ (s.e.) could be estimated if this depression was ignored. The selective $\mathrm{CCK}_{\mathrm{B}}$ antagonist, L-365,260 (0.01-0.3 $\left.\mu \mathrm{M}\right)$ antagonized competitively the CCK-4 induced contraction and a $\mathrm{p} K_{\mathrm{B}}$ of $8.60 \pm 0.16$ (s.e.) was estimated.

3 The combined dose-ratio analysis for virginiamycin, tested at 3 and $10 \mu \mathrm{M}$ in association with 0.03 and $0.1 \mu \mathrm{M}$ L-365,260, respectively, resulted in observed log dose-ratios of 1.39 and 1.53. That was consistent with both antagonists acting on the same receptor in LMMP.

4 These data, represent the first evidence of the antagonism of virginiamycin in a functional assay and they support the hypothesis of homogeneity between $\mathrm{CCK}_{\mathrm{B}}$ receptors in the CNS and in peripheral tissues.

Keywords: Guinea-pig ileum; cholecystokinin; L-365,260; virginiamycin; $\mathrm{CCK}_{\mathrm{B}}$ receptor

\section{Introduction}

Cholecystokinin (CCK) causes marked peripheral and central effects by interacting with two different types of receptor, $\mathrm{CCK}_{\mathrm{A}}$ and $\mathrm{CCK}_{\mathrm{B}}$ (Bock, 1991). The former is largely distributed in the periphery and the latter is found in most abundance in the CNS (Bock et al., 1989; Woodruff \& Hughes, 1991). The two receptors have been distinguished by use of both selective agonists (e.g. CCK-4 for $\mathrm{CCK}_{\mathrm{B}}$ receptors) and selective antagonists (e.g. L-364,718 (3S(-)-N-(2,3dihydro-1-methyl-2-oxo-5-phenyl-1H-1,4-benzodiazepine-3yl)$1 \mathrm{H}$-indole-2-carboxamide) for $\mathrm{CCK}_{\mathrm{A}}$ receptors and L-365,260 ( $(3 \mathbf{R}(+)$-2,3-dihydro-1-methyl-2-oxo-5-phenyl-1H-1,4-benzodiazepine-3yl)-N-(3-methylphenyl)-urea) for $\mathrm{CCK}_{\mathrm{B}}$ receptors, Chang \& Lotti, 1986; Lotti \& Chang, 1989). Differences between $\mathrm{CCK}_{\mathrm{B}}$ receptors and gastrin receptors, although suggested (Patel \& Spraggs, 1992; Botella et al., 1992), have, as yet, not been clearly demonstrated. Recently, the guinea-pig ileum longitudinal muscle myenteric plexus (LMMP) has been shown to contain neuronal receptors for both the $\mathbf{C C K}_{\mathrm{A}}$ and $\mathrm{CCK}_{\mathrm{B}}$ sub-types (Lucaites et al., 1991; Dal Forno et al., 1992). Thus, in the presence of a selective $C_{C C} K_{A}$ receptor antagonist such as L-364,718, LMMP could be considered as a functional assay for $\mathrm{CCK}_{\mathrm{B}}$ receptors.

Selective antagonists for the $\mathrm{CCK}_{\mathrm{B}}$ receptor, so far described, tend to fall into a number of discrete chemical classes. These include the benzodiazepines, peptoids and the pyrazolidinones (Kervin, 1991). In addition, virginiamycin, a macrolide antibiotic produced by fermentation of a strain of Streptomyces olivaceous, has been reported to bind to $\mathrm{CCK}_{\mathrm{B}} /$ gastrin receptors (Lam et al., 1991). Thus, in radiolabelled binding studies virginiamycin has an $\mathrm{IC}_{50}(\mathrm{nM})$ of 571 and 710 for CCK $_{B}$ (guinea-pig brain) and gastrin (guinea-pig gastric glands) receptors, respectively, with no apparent affinity for $\mathrm{CCK}_{\mathrm{A}}$ (rat pancreas) receptors $(>100,000 \mathrm{nM})$. To date it has not been reported whether virginiamycin acts as an agonist or an antagonist at $\mathrm{CCK}_{\mathrm{B}}$ receptors. Thus the objective of the study described below was to determine and to quantify the nature of the interaction of virginiamycin with $\mathbf{C C K}_{\mathrm{B}}$ receptors in a functional assay, namely LMMP.

'Author for correspondence.

\section{Methods}

Male Dunkin-Hartley guinea-pigs weighing approximately $300-400 \mathrm{~g}$ were allowed free access to food and water until just before use. The animals were killed by cervical dislocation and $10 \mathrm{~cm}$ of terminal ileum was rapidly removed and placed in a modified Krebs solution (composition, mM: $\mathrm{NaCl}$ 118.5, $\mathrm{CaCl}_{2}$ 1.2, $\mathrm{KCl} 4.7, \mathrm{MgSO}_{4} 0.6, \mathrm{NaHCO}_{3} 25, \mathrm{KH}_{2} \mathrm{PO}_{4}$ 1.2 , glucose 11.1). A $4 \mathrm{~cm}$ length of ileum was placed over a glass-pipette and the longitudinal muscle with adherent myenteric plexus was removed with a cotton tip. The preparations were set-up in $2 \mathrm{ml}$ sylanized (5\% dimethylchloroxylane $95 \%$ toluene) baths at $37^{\circ} \mathrm{C}$ containing the Krebs solution gassed with a $5 \% \mathrm{CO}_{2}: 95 \% \mathrm{O}_{2}$ mixture. The muscle was attached to an isotonic transducer (Ugo Basile 7006) coupled to a polygraph (Ugo Basile Gemini 7070 and Unirecord 7050). The tissues were washed and adjusted to a tension of $0.5 \mathrm{~g}$. After a resting phase of $60 \mathrm{~min}$ the tissues were challenged several times with 1,1-dimethyl-4-phenylpiperazinium iodide (DMPP) $30 \mu \mathrm{M}$ at a cycle time of $10 \mathrm{~min}$ until a constant response was achieved.

\section{Experimental protocol}

All the experiments described here were performed with Krebs solution containing L-364,718 at $10 \mathrm{nM}$. Each tissue received only one treatment. Serial concentration-response curves (CRC) for the agonist CCK-4 were run at intervals of $10 \mathrm{~min}$. When evaluating the effect of the antagonist virginiamycin, L-365,260 or the mixture of both, a $60 \mathrm{~min}$ contact time was allowed before the first administration of the agonist. The antagonist or the mixture of antagonists was left in contact with the tissue throughout the duration of the experiment. The contractions measured were expressed as a percentage of the effect obtained with $30 \mu \mathrm{M}$ DMPP.

\section{Analysis of data}

Curve fitting The CRC data were routinely fitted by a four parameter logistic equation (De Lean et al., 1978):

$$
\text { response }=a+\frac{R_{\max }[A]^{n}}{[A]^{n}+\left[A_{50}\right]^{n}}
$$


where a and $\mathbf{R}_{\max }$ are the minimum and maximal asymptotes respectively, [A] the agonist concentration, $\mathrm{n}$ the slope factor and $\left[\mathrm{A}_{50}\right]$ the concentration of the agonist that induces $50 \%$ of the maximal effect $\left(E D_{50}\right)$. Antagonism were tested for significant differences in parallelism and of maximal responses in comparison with the control. If no significant difference was found, the analysis of the antagonist effect was performed.

Analysis of individual antagonist effects Curve displacements by antagonists applied singly were analysed fitting CRC data to the equation:

$$
\text { response }=\frac{\mathrm{R}_{\max }[\mathrm{A}]^{\mathrm{n}}}{\left(\left(\left[\mathrm{A}_{50}\right]^{\mathrm{n}}\right)\left(1+\left([\mathrm{B}]^{\mathrm{m}} / K_{\mathrm{B}}\right)\right)^{\mathrm{n}}+[\mathrm{A}]^{\mathrm{n}}\right)}
$$

where $R_{\max },[A], n$ and $\left[A_{50}\right]$ are as above defined, $B$ is the antagonist concentration, $\mathrm{m}$ is the equivalent to the Schild slope parameter and $K_{\mathrm{B}}$ is the antagonist dissociation constant when $m$ is not significantly different from one.

Combined dose-ratio analysis This analysis was performed according to the procedure developed by Shankley et al. (1988). The theory predicts that when two antagonists (A and C) act through an interaction at the same receptor to produce their effect (additive model), then the measured dose-ratio should be:

$$
\mathrm{DR}_{\mathrm{A}+\mathrm{C}}=\mathrm{DR}_{\mathrm{A}}+\mathrm{DR}_{\mathrm{C}}-1
$$

where $D_{R_{A}}$ and $D R_{C}$ are the dose ratio obtained independently in the presence of the antagonist $A$ and $C$. The model was tested by comparing the discrepancy between observed and expected statistics for the models with estimates of their standard errors. Thus, for the additive model:

$$
\mathrm{S}_{\mathrm{A}}=\log E \mathrm{D}_{50 \mathrm{AC}}-\log \left(\mathrm{ED}_{50 \mathrm{~A}}+\mathrm{ED}_{50 \mathrm{C}}-\mathrm{ED}_{50}\right)
$$

where $\mathrm{ED}_{50 \mathrm{AC}}, \mathrm{ED}_{50 \mathrm{~A}}, \mathrm{ED}_{50 \mathrm{C}}$ and $\mathrm{ED}_{50}$ are the concentrations of agonist that induce $50 \%$ of response in the presence of the mixture of the antagonists $\mathrm{AC}$, only $\mathrm{A}$ or only $\mathrm{C}$ and in the absence of both (control) respectively. The term $S_{A}$ is the test statistic of the model which will have a value of zero when the data comply with the model.

Similarly, when the two antagonists act independently (multiplicative model) the measured dose-ratio should be:

$$
\mathrm{DR}_{\mathrm{A} \cdot \mathrm{C}}=\mathrm{DR}_{\mathrm{A}} * \mathrm{DR}_{\mathrm{C}}
$$

For the multiplicative model the test statistic of the model is:

$$
\mathrm{S}_{\mathrm{M}}=\log E \mathrm{D}_{50 \mathrm{AC}}+\log E \mathrm{D}_{50}-\log E \mathrm{D}_{50 \mathrm{~A}}-\log E \mathrm{D}_{50 \mathrm{C}}
$$

so that $S_{M}$, the test statistic will be zero when the data comply with the model.

From the combined dose ratio analysis the dissociation constant $\left(K_{\mathrm{B}} \mathrm{v}\right)$ for virginiamycin was estimated using the equation (Black et al., 1986; Leff \& Morse, 1987; Trist et al., 1987):

$$
\mathrm{DR}_{\mathrm{AC}}=1+\frac{[\mathrm{A}]}{K_{\mathrm{B}} \mathrm{I}\left(1+[\mathrm{C}] / K_{\mathrm{B}} \mathrm{v}\right)}
$$

where $\mathrm{DR}_{\mathrm{AC}}$ in this case is the dose-ratio obtained with both antagonists (A and $C$ ) together, measured from the curve produced in the presence of $\mathrm{C}$ alone, [A] is the concentration of the standard (L-365,260) and $K_{\mathrm{B}} \mathrm{I}$ is its dissociation constant.

Values are given \pm s.e.mean.

\section{Drugs used}

The following drugs were used: cholecystokinin tetrapeptide (CCK-4) and DMPP, both from Sigma. L-364,718, L-365,260 and virginiamycin were synthesized by the chemistry depart- ment of Glaxo Italy. DMPP was dissolved in water, whereas CCK-4 (at $30 \mathrm{mM}$ ) and L-364,718, L-365,260 and virginiamycin (all three at $100 \mu \mathrm{M}$ ) were dissolved in dimethylsulphoxide. Further dilutions were made in distilled water. Vehicles were found not to produce significant effects on the CCK-4-induced contraction.

\section{Results}

CCK-4 (0.01-300 $\mu \mathrm{M})$, as has already been reported (Dal Forno et al., 1992), contracted the LMMP showing a biphasic CRC. In the same study it was demonstrated that this effect was due to the activation of both types of CCK receptors, with a higher potency of CCK-4 for the CCK $_{B}$ type. In the presence of $\mathrm{L}-364,718$ at $10 \mathrm{nM}$, the CCK-4 CRC changes into a mono-phasic curve with a suppression of the upper part, the $\mathrm{CCK}_{\mathrm{A}}$-activated region (Figure 1). To avoid possible interaction with $\mathrm{CCK}_{\mathrm{A}}$ receptors, all further experiments described in the present study were carried out in the presence of $10 \mathrm{nM} \mathrm{L-364,718.}$

\section{Analysis of individual antagonistic effects}

L-365,260 (0.01-0.3 $\mu \mathrm{M})$ antagonized CCK-4-induced contractions in a competitive manner (Figure 2). The Schild slope parameter was $1.25 \pm 0.15(95 \%$ CL $0.93-1.56)$ which was not significantly different from one $(P=0.10)$. The analysis of the antagonism resulted in a $\mathrm{p} K_{\mathrm{B}}$ of $8.60 \pm 0.16$ (Figure 2). Virginiamycin $(1-10 \mu \mathrm{M})$ antagonized in a doserelated manner the CCK-4 CRC. However, at the highest concentration, virginiamycin caused a significant $(P=0.001)$ reduction of the maximal response to the agonist (Figure 3 ). An apparent dissociation constant $\left(\mathrm{pA}_{2}\right)$ was, however, estimated without any assumption of the mechanism of action. It was $6.64 \pm 0.06$. Comparing the two antagonists, virginiamycin is about 100 fold less potent than L-365,260. Virginiamycin over the range 0.3 to $10 \mu \mathrm{M}$ did not contract the LMMP (data not shown).

\section{Combined dose-ratio analysis}

The effect of the two antagonists acting alone and in combination are shown in Figures 4 and 5 . The concentrations were chosen to give a similar individual displacement. Figure 4 demonstrates the effect of L-365,260 $0.03 \mu \mathrm{M}(n=4)$ and virginiamycin $3 \mu \mathrm{M}(n=4)$ when given alone or in combination $(n=4)$. Thus, if addition of the dose-ratio occurred then

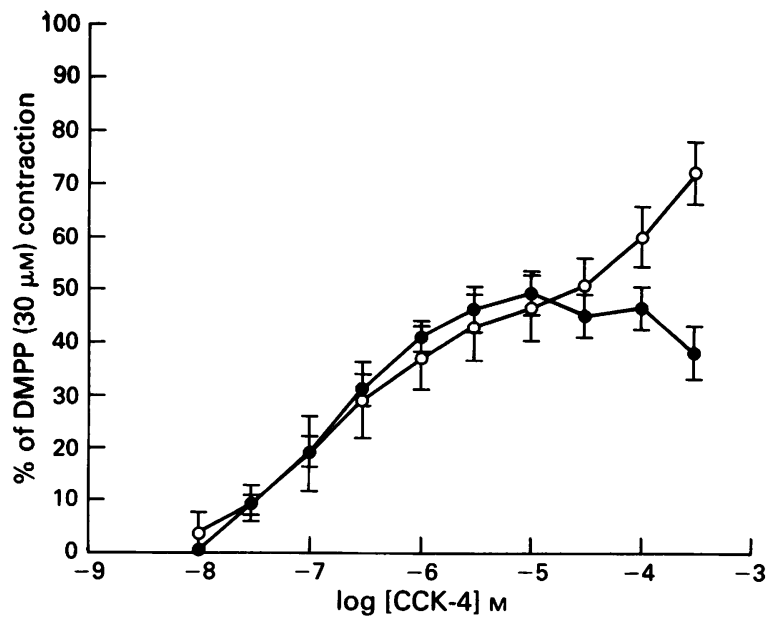

Figure 1 Concentration-response curve for cholecystokinin tetrapeptide (CCK-4) alone $(O)$ and in the presence of $10 \mathrm{nM} \mathrm{L-364,718(O)}$. Each point represents the mean \pm s.e. of 7 replications. 


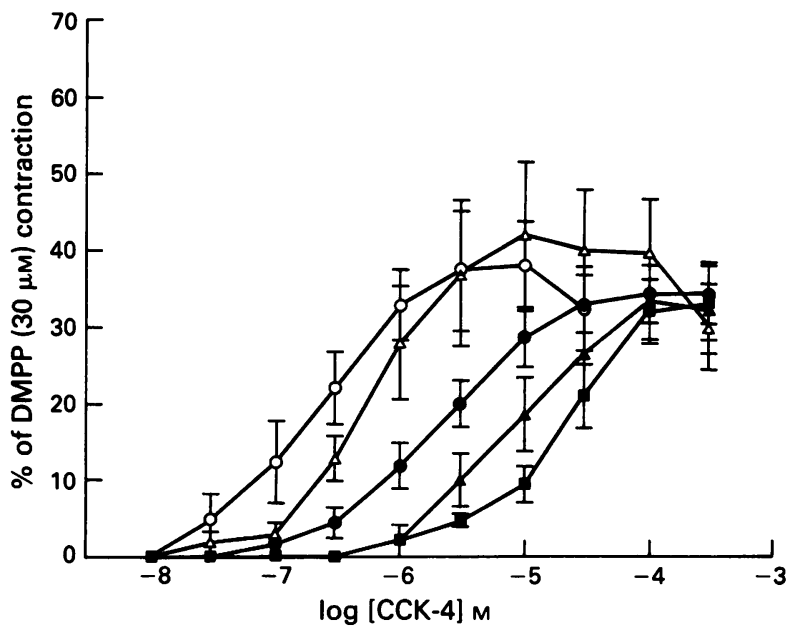

Figure 2 Concentration-response curve for cholecystokinin tetrapeptide $(C C K-4)$ alone $(O)$ and in the presence of L365,260: $0.01 \mu \mathrm{M}$ $(\Delta), 0.03 \mu \mathrm{M}(\Theta), 0.1 \mu_{\mathrm{M}}(\Delta)$ and $0.3 \mu_{\mathrm{M}}(\square)$. All the experiments were carried out in the presence of $10 \mathrm{nM}$ L-364,718 and each point is the mean \pm s.e. of $5-10$ replications.

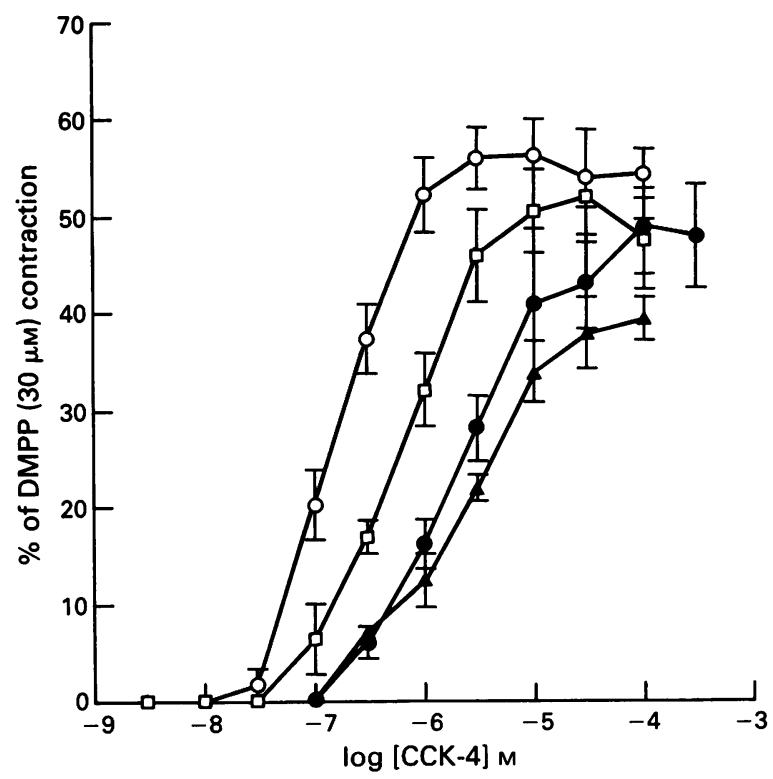

Figure 3 Concentration-response curve for cholecystokinin tetrapeptide (CCK-4) alone $(O)$ and in the presence of virginiamycin: $1 \mu \mathrm{M}$ (口), $3 \mu \mathrm{M}(O)$ and $10 \mu \mathrm{M}(\Delta)$. All the experiments were carried out

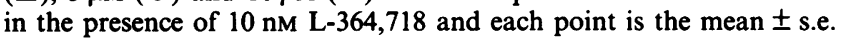
of 4 replications.

the predicted combined log dose-ratio would have been 1.32 . On the other hand if the dose-ratios were multipled, then the $\log$ dose-ratio would have been 2.06. Figure 5 shows the effect of higher concentrations of the two antagonists, L$365,2600.1 \mu \mathrm{M}(n=4)$ and virginiamycin $10 \mu \mathrm{M}(n=4)$ when given alone or in combination $(n=4)$. With these concentrations, if addition of the dose-ratios occurred then the predicted $\log$ dose-ratio would have been 1.49. For the multiplicative model the predicted log dose-ratio would have been 2.37. The data obtained in both experiments were consistent with the additive model and rejected the multiplicative model. In fact the observed log dose-ratios were 1.39 and 1.53 (Table 1). A simulation of the multiplicative model for both experiments have been included in both Figures 4 and

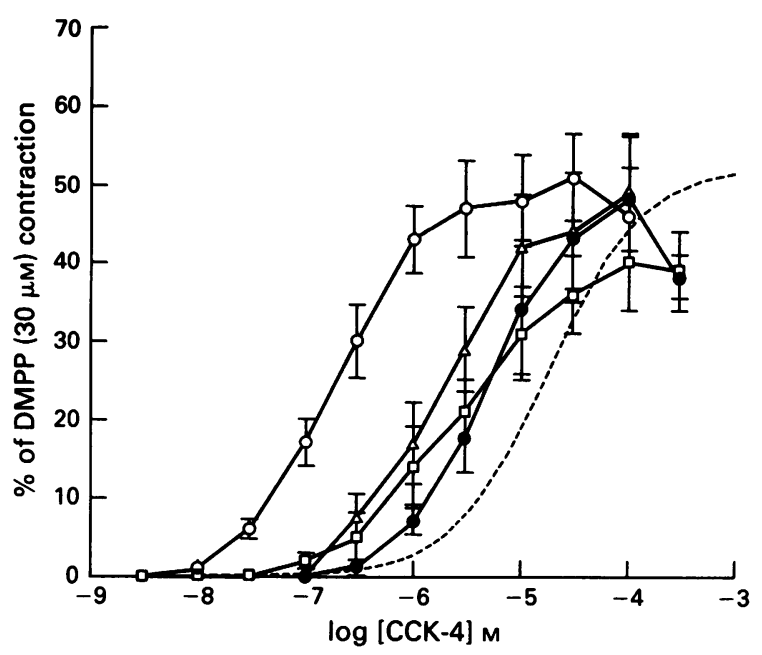

Figure 4 Concentration-response curve for cholecystokinin tetrapeptide $(\mathrm{CCK}-4)$ alone $(\mathrm{O})$ and in the presence of $3 \mu \mathrm{M}$ virginiamycin $(\Delta), 0.03 \mu \mathrm{M}$ L-365,260 (口) and a combination of $3 \mu \mathrm{M}$ virginiamycin and $0.03 \mu \mathrm{M} \mathrm{L-365,260}$ (O). All the experiments were

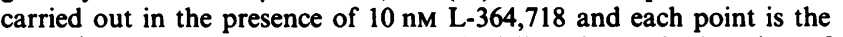
mean \pm s.e. of 4 replications. The dashed line shows the location of the CCK-4 concentration-response curve which was predicted by assuming that the antagonists acted independently.

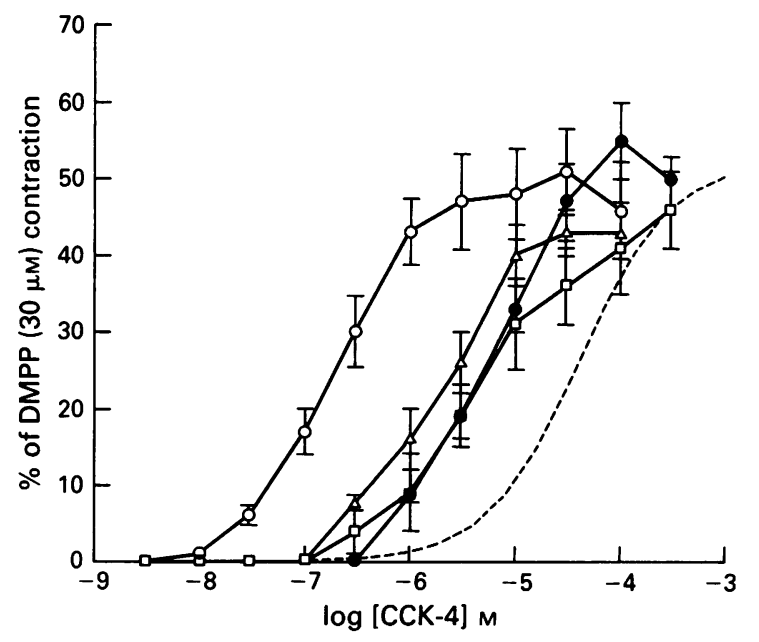

Figure 5 Concentration-response curve for cholecystokinin tetrapeptide $(\mathrm{CCK}-4)$ alone $(O)$ and in the presence of $10 \mu \mathrm{M}$ virginiamycin $(\Delta), 0.1 \mu \mathrm{M}$ L-365,260 (口) and a combination of $10 \mu \mathrm{M}$ virginiamycin and $0.1 \mu \mathrm{M}$ L-365,260 (O). All the experiments were

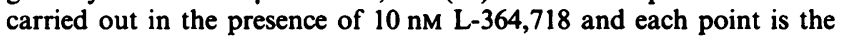
mean \pm s.e. of 4 replications. The dashed line shows the location of the CCK-4 concentration-response curve which was predicted by assuming that the antagonists acted independently.

5. From the combined dose-ratio analysis the $\mathrm{p} K_{\mathrm{B}}$ for virginiamycin estimated from equation (7) was 6.20 and 6.14 when virginiamycin was tested at 3 and $10 \mu \mathrm{M}$ respectively.

\section{Discussion}

To date, little has been reported on $\mathrm{CCK}_{\mathrm{B}}$ antagonists in in vitro functional assays. Of those antagonists so far described, L-365,260, the first selective CCK $_{B}$ antagonist discovered, has become somewhat of a standard, particularly in biochemical and in vivo assay (Bock et al., 1989). Also, L-365,260 has 
Table 1 Combined dose-ratio analysis of virginiamycin with L-365,260 used as a standard CCK $_{B}$ antagonist

\begin{tabular}{|c|c|c|c|}
\hline & $\begin{array}{l}\text { A } \\
\text { C }\end{array}$ & $\begin{array}{l}\text { L-365,260 } \\
(0.03 \mu \mathrm{M}) \\
\text { VGM }(3 \mu \mathrm{M})\end{array}$ & $\begin{array}{l}\text { L-365,260 } \\
(0.1 \mu \mathrm{M}) \\
\text { VGM }(10 \mu \mathrm{M})\end{array}$ \\
\hline Observed & $\begin{array}{l}\log R_{A} \\
\log R_{C}\end{array}$ & $\begin{array}{l}1.11 \\
0.94\end{array}$ & $\begin{array}{l}1.33 \\
1.06\end{array}$ \\
\hline $\begin{array}{l}\text { Multiplicative } \\
\text { expected } \\
\text { Additive }\end{array}$ & $\log R_{A \cdot C}$ & 2.06 & 2.37 \\
\hline $\begin{array}{l}\quad \begin{array}{l}\text { expected } \\
\text { observed }\end{array} \\
S_{\mathrm{A}} \pm \text { s.e. } \\
S_{M} \pm \text { s.e. }\end{array}$ & $\begin{array}{l}\log R_{A}+C \\
\log R_{A C}\end{array}$ & $\begin{array}{l}1.32 \\
1.39 \\
0.075 \pm 0.167 \\
0.660 \pm 0.292^{*}\end{array}$ & $\begin{array}{l}1.49 \\
1.53 \\
0.027 \pm 0.155 \\
0.810 \pm 0.076^{*}\end{array}$ \\
\hline
\end{tabular}

*Significantly different from zero $(P<0.05)$

VGM = virginiamycin

$S_{A}$ and $S_{M}$ were derived as described in the methods.

been analysed functionally in vitro in the guinea-pig ileum (Lucaites et al., 1991; Dal Forno et al., 1992).

In these studies its estimated affinity $\left(\mathrm{p} K_{\mathrm{B}}\right)$ was similar to that reported in binding studies using brain homogenates (Bock et al., 1989). Thus, in this study L-365,260 has been taken as the standard antagonist against which to test virginiamycin.

The structure of virginiamycin is considerably different from other known $\mathrm{CCK}_{\mathrm{B}}$ receptor ligands. This raises the questions as to the nature of its interaction with the receptor (agonist or antagonist) and whether virginiamycin might discriminate between central and peripheral $C_{C C K}$ receptors. These questions do not appear to have been addressed previously, as until now, only binding data have been reported.

In the LMMP, virginiamycin showed antagonistic activity for $\mathrm{CCK}-4$, in conditions where $\mathrm{CCK}_{\mathrm{A}}$ receptor activation had been blocked. No agonism was observed. However, the antagonism was not of a simple competitive nature as at $10 \mu \mathrm{M}$ a significant reduction of the maximal response was seen. To evaluate further whether this depression is related to another mechanism of action of virginiamycin, combined dose ratio analysis was applied. This was justified since L-
365,260 was available as a reliable standard antagonist. Combined dose-ratio analysis has become a powerful method for disecting out complex antagonism. In this case the results are consistent with a model of L-365,260 and virginiamycin both acting on the same receptor. In fact, in experiments where L-365,260 and virginiamycin were applied in combination, a protection of the depressant effect was observed. Thus, the reduction of the maximal response seems to be related to an interaction of virginiamycin with the $\mathrm{CCK}_{\mathrm{B}}$ receptor. This might indicate that virginiamycin at high concentrations has a relatively slow off rate, or that a mechanism similar to that described by Liu et al. (1992) is involved, where antagonists might change the efficacy of an agonist. Further experiments are needed to elucidate those possibilities. The $\mathrm{p} K_{\mathrm{B}}$ estimated for virginiamycin from the combined dose-ratio analysis was 6.2 which seemed to reflect its true affinity for virginiamycin on the $\mathrm{CCK}_{\mathrm{B}}$ receptor in LMMP as this value was not significantly different from the affinity estimated in binding assays.

This was calculated from the $\mathrm{IC}_{50}$ values reported by Lam et al. (1991) as 6.24 using a concentration of radioligand equal to or less than its $K_{\mathrm{A}}$ value. The $\mathrm{pA}_{2}$ calculated for virginiamycin using Schild analysis, where the depressant property has been ignored, gives a larger value of 6.64 . The difference between this and the estimated $\mathrm{p} K_{\mathrm{B}}$ is significant $(P<0.05)$ using the standard error on the $\mathrm{pA}_{2}$ estimation. It is not possible to define the standard error from the combined dose-ratio analysis as all of the data was pooled to perform the analysis. The difference probably reflects the influence of the depressant effect.

A comparison between the $\mathrm{p} K_{\mathrm{B}}$ estimated in our study with the $\mathrm{p} K_{\mathrm{i}}$ obtained from binding data, as decribed above (Lam et al., 1991), suggests that virginiamycin does not discriminate between peripheral and central $\mathrm{CCK}_{\mathrm{B}}$ receptors. The close convergence between the two estimates (6.2 and 6.24 , respectively), however, does rely on the assumption that the $\mathrm{p} K_{\mathrm{i}}$ can be obtained from the $\mathrm{IC}_{50}$ using the Cheng \& Prusoff equation (1973). This itself requires that the antagonist-receptor interaction follows the law of massaction.

In conclusion, these results have shown, for the first time, that virginiamycin acts as $\mathrm{CCK}_{B}$ receptor antagonist in a functional assay.

\section{References}

BLACK, JW GERSKOWITCH, V.P, LEFF, P \& SHANKLEY, N.P. (1986). Analysis of competitive antagonism when this property occurs as part of a pharmacological resultant. Br. J. Pharmacol., $89,547-555$

BOCK, M. (1991). Development of non peptide cholecystokinin type B receptor antagonists. Drugs of the Future, 16, 631-640.

BOCK, M.H., DIPARDO, R.M., EVANS, B.E., RITTLE, K.E., WHITTER, W.L., VEBER, D.F., ANDERSON, P.S. \& FREIDINGER, R.M. (1989). Benzodiazepine gastrin and brain cholecystokinin receptor ligands: L-365,260. J. Med. Chem., 89, 13-16.

BOTELLA, A., DELVAUX, M., BERRY, P., FREXINOS, J. \& BUENO, L. (1992). Cholecystokinin and gastrin induced cell contraction in pig ileum by interacting with different receptor subtypes. Gastroenterology, 102/3, 779-786.

CHANG, R.S.L. \& LOTTI, V.J. (1986). Biochemical and pharmacological characterisation of an extremely potent and selective non-peptide cholecystokinin antagonist. Proc. Natl. Acad. Sci. U.S.A. 83, 4923-4926.

CHENG, Y.C. \& PRUSOFF, W.H. (1973). Relationship between the inhibition constant $(\mathrm{Ki})$ and the concentration of inhibitor that causes 50 percent inhibition $\left(I_{50}\right)$ of an enzymatic reaction. Biochem. Pharmacol., 22, 3099-3108.

DAL FORNO, G., PIETRA, C., URCIUOLI, M., VAN AMSTERDAM, F., TOSON, G., GAVIRAGHI, G. \& TRIST, D. (1992). Evidence for two cholecystokinin receptors mediating the contraction of the guinea pig isolated ileum longitudinal-myenteric plexus. J. Pharmacol. Exp. Ther., 261, 1056-1063.
DE LEAN, A., MUNSON, P.J. \& RODBARD, D. (1978). Simultaneous analysis of families of sigmoidal curves: application to bioassay, radioligand assay and physiological dose-response curves. Am. J. Physiol., 235, 97-102.

KERVIN, J.F. Jr. (1991). Further developments in cholecystokinin antagonist research. Drugs of the Future, 16, 1111-1119.

LAM, Y.K.T., BOGEN, D., CHANG, R.S., FAUST, K.A., HENSENS, O.D., ZINC, D.L., SCHWARTZ, C.D., ZITANO, L., GARRITY, G.M., GAGLIARDI, M.M., CURRIE, S.A. \& WOODRUFF, H.B. (1991). Novel and potent gastrin and brain cholecystokinin antagonists from streptomyces olivaceus. Taxonomy, fermentation, isolation, chemical conversions, and physico-chemical and biochemical properties. J. Antibiotics, 44, 613-634.

LEFF, P. \& MORSE, J.M. (1987). Resultant pharmacological actions of verapamile: quantification of competitive 5-hydroxytryptamine antagonism in combination with calcium antagonism. J. Pharmacol. Exp. Ther., 240, 284-287.

LIU, Y.J., SHANKLEY, N.P., WELSH, N.J. \& BLACK, J.W. (1992). Evidence that the apparent complexity of receptor antagonism by angiotensin II analogues is due to a reversible and syntopic action. Br. J. Pharmacol., 106, 233-241.

LOTTI, V.J. \& CHANG, R.S.L. (1989). A new potent and selective non-peptide gastrin antagonist and brain cholecystokinin receptor (CCK-B) ligand: L-365,260. Eur. J. Pharmacol., 162, 273-280. 
LUCAITES, V.L., MENDELSOHN, L.G., MASON, N.R. \& COHEN, M.L. (1991). CCK-8, CCK-4 and gastrin-induced contraction of guinea pig ileum: evidence for differential release of acetylcholine and substance $\mathrm{P}$ by CCK-A and CCK-B receptors. J. Pharmacol. Exp. Ther., 256, 695-703.

PATEL, M. \& SPRAGGS, C.F. (1992). Functional comparison of gastrin/cholecystokinin receptors in isolated preparations of gastric mucosa and ileum. Br. J. Pharmacol., 106, 275-282.

SHANKLEY, N.P., BLACK, J.W., GANELLIN, C.R. \& MITCHELL, R.C. (1988). Correlation between $\log \mathrm{P}_{\mathrm{OCT}} \mathrm{H}_{2} \mathrm{O}$ and $\mathrm{pK}_{\mathrm{B}}$ estimates for a series of muscarinic and histamine $\mathrm{H}_{2}$-receptor antagonists. $\mathrm{Br}$. J. Pharmacol., 94, 264-274.
TRIST, D.G., LEFF, P., BLACK, J.W., GERSKOWITCH, V.P. \& SHANKLEY, N.P. (1987). Resultant action of cimetidine in a cardiac adenylate cyclase assay; its elucidation by concentration-ratio analysis. J. Pharmacol. Exp. Ther., 243/3, 1043-1047.

WOODRUFF, G.N. \& HUGHES, J. (1991). Cholecystokinin antagonists. Annu. Rev. Pharmacol. Toxicol., 31, 469-501.

(Received July 28, 1992

Revised November 11, 1992 Accepted December 22, 1992) 